\title{
Excellent superiority and specificity of COBAS TaqMan HCV assay in an early viral kinetic change during pegylated interferon alpha-2b plus ribavirin treatment
}

\author{
Eiichi Ogawa ${ }^{\dagger 1}$, Norihiro Furusyo*11,2, Kazuhiro Toyoda' ${ }^{*}$ Hiroaki Taniai', Shigeru Otaguro', Mosaburo Kainuma', \\ Masayuki Murata', Yasunori Sawayama' and Jun Hayashi1,2
}

\begin{abstract}
Background: An early virological response (EVR) after the start of interferon (IFN) treatment for chronic hepatitis C leads to a successful virological outcome. To analyze an association between sustained virological response (SVR) and EVR by comparing TaqMan with Amplicor assays in HCV genotype 1-infected patients treated with pegylated (PEG)-IFN alpha-2b plus ribavirin (RBV).

Methods: We retrospectively analyzed a total of 80 HCV genotype 1 patients (39 SVR and 41 non-SVR patients), who received an enough dosage and a complete 48-week treatment of PEG-IFN alpha-2b plus RBV. Serum HCV RNA levels were measured by both TaqMan and Amplicor assays for each patients at Weeks 2, 4, 8 and 12 after the start of the antiviral treatment.
\end{abstract}

Results: Of the 80 patients with undetectable HCV RNA by Amplicor, 17 (21.3\%) patients were positive for HCV RNA by TaqMan at Weeks 12. The quantification results showed that no significant difference in the decline of HCV RNA level between TaqMan and Amplicor 10-fold method assays within the initial 12 weeks of the treatment was found. However, the qualitative analysis showed significant differences of the positive predictive rates for SVR were found between TaqMan (100\% at weeks 4 and 100\% at weeks 8 ) and Amplicor ( $80.0 \%$ and 69.6\%, respectively).

Conclusions: The COBAS TaqMan HCV assay is very useful for monitoring HCV viremia during antiviral treatment to predict a SVR in HCV genotype 1 patients.

\section{Background}

The hepatitis $\mathrm{C}$ virus (HCV) infection is a main cause of viral chronic hepatitis in Japan, where approximately 1.8 million patients have HCV infection. The prognosis of liver fibrosis made by wound-healing response to chronic liver injury may lead to cirrhosis $[1,2]$.

The most current antiviral treatment for chronic $\mathrm{HCV}$ infection is pegylated interferon (PEG-IFN) alpha in combination with ribavirin (RBV), which has been used in worldwide $[3,4]$. The combination treatment has resulted in a higher rate of sustained virological response

*Correspondence: furusyo@gim.med.kyushu-u.ac.jp

1 Department of General Internal Medicine, Kyushu University Hospital,

Fukuoka, Japan

+ Contributed equally

Full list of author information is available at the end of the article
(SVR) than standard interferon (IFN) monotherapy [5,6]. The predictor of IFN treatment response such as $\mathrm{HCV}$ genotype, HCV RNA level, age, sex, the stage of liver fibrosis, the duration and dose of antiviral treatment and so on has been reported previously [7-9]. Otherwise, the predictive factor of antiviral efficacy after the start of antiviral treatment has been studied by $\mathrm{HCV}$ dynamics, which the duration of virological clearance of HCV RNA is associated with the therapeutic efficacy. Especially, an early viral response (EVR), a virological clearance by antiviral treatment within the initial 12 weeks, is significantly correlated with SVR in the treated patients [10-12].

Quantifying serum HCV RNA level helps to evaluate the efficacy and monitoring of antiviral treatment. Both qualitative and quantitative $\mathrm{HCV}$ RNA assay using 
COBAS Amplicor system (Amplicor) has been used well in clinical [13]. Recently, COBAS TaqMan HCV assay (TaqMan) equipped with highly detection sensitivity and widely measuring range has been developed, and this has enabled to measure qualitative and quantitative analysis simultaneously $[14,15]$. The aim of the present study is to analyze an association between SVR and EVR by comparing TaqMan with Amplicor assays in patients with HCV genotype 1 infection who has been treated with PEG-IFN alpha-2b plus RBV.

\section{Methods \\ Patients}

A retrospective study of 80 Japanese genotype 1-infected chronic hepatitis $\mathrm{C}$ patients who were treated with 48week PEG-IFN alpha-2b plus RBV was done from January 2005 to July 2007, in order to analyze an association between sustained virological response (SVR) and early virological response (EVR) by comparing TaqMan with Amplicor assays. To exactly consider an association between antiviral response and viral kinetics, we selected all 80 patients who received both PEG-IFN alpha-2b $80 \%$ or over and RBV $60 \%$ or over of the target dosage of 48 week [16]. Using COBAS Amplicor HCV Monitor Test v2.0 (qualitative Amplicor), the 80 selected patients were negative for HCV RNA during the treatment and no patients with positivity HCV RNA during the treatment were included in this study.

SVR was defined as serum HCV RNA undetectable at 24 weeks after the end of treatment. Patients who had undetectable HCV RNA within the initial 12 weeks of treatment were considered to have had an EVR. Of the 80 patients, 39 achieved SVR at 24 weeks after the end of treatment, and 41 had clearance of $\mathrm{HCV}$ viremia during the treatment but achieved non-SVR after the end of the treatment.

All patients were satisfied the following criteria. Criteria for exclusion were: (i) clinical or biochemical evidence of hepatic decompensation, advanced cirrhosis identified by large esophageal varices (F2 or F3), history of gastrointestinal bleeding, ascites, encephalopathy, or hepatocellular carcinoma; (ii) hemoglobin level $<115 \mathrm{~g} / \mathrm{L}$, white blood cell count $<3 \times 10^{9} / \mathrm{L}$, and platelet count $<50 \times$ $10^{9} / \mathrm{L}$; (iii) concomitant liver disease other than hepatitis C (hepatitis B surface antigen positive or human immunodeficiency virus antibody positive); (iv) excessive active alcohol consumption (> $60 \mathrm{~g} /$ day converted into ethanol) or drug abuse; (v) severe psychiatric disease; and (vi) antiviral or corticosteroid therapy within 12 months prior to the enrolment. Patients who fulfilled the above criteria were recruited at the Department of General Internal Medicine, Kyushu University Hospital.

The diagnosis of chronic hepatitis and cirrhosis was based on a liver biopsy in each patient. All patients were diagnosed with chronic active hepatitis with piecemeal necrosis or fibrosis formation of portal-portal bridging. No significant differences were observed between these group patients at entry.

Clinical and biochemical characteristics of the enrolled 80 patients with chronic HCV infection are summarized in Table 1. The mean age of SVR patients was significantly lower $(54.8 \pm 9.3$ years $)$ than that of non-SVR patients $(59.8 \pm 9.7$ years $)(P=0.0133)$. No significant differences were found in the means for body mass index, alanine aminotransferase, $\gamma$-glutamyl-transpeptidase or platelet count between SVR and non-SVR patient groups.

The study was conducted in accordance with the ethical guidelines of the Declaration of Helsinki and the International Conference on Harmonization of guidelines for good clinical practice.

\section{Therapeutic protocol}

All patients were treated with a weight-based, $1.5 \mu \mathrm{g} / \mathrm{kg}$ weekly dose of subcutaneous PEG-IFN alpha-2b (PegIntron A; Schering-Plough, Osaka, Japan). In combination with PEG-IFN alpha-2b, RBV (Rebetol; Schering-Plough) was given orally at a daily dose of 600-1,000 mg based on bodyweight $(600 \mathrm{mg}$ for patients weighing $<60 \mathrm{~kg}, 800$ $\mathrm{mg}$ for those weighing $60-80 \mathrm{~kg}$, and 1,000 $\mathrm{mg}$ for those weighing $>80 \mathrm{~kg}$ ). The length of the combined treatment was 48 weeks. The above duration and dosage are those approved by the Japanese Ministry of Health, Labor and Welfare. Patients were considered to have RBV-induced anemia if the hemoglobin level decreased to $<100 \mathrm{~g} / \mathrm{L}$. In such cases, a reduction in the dose of RBV was required. Some patients also had PEG-IFN alpha-2b induced psychological adverse effects or a decrease of white blood cell and platelet count. In such cases, a reduction in the dosage of PEG-IFN alpha-2b was required. Both PEGIFN alpha-2b and RBV were discontinued if the hemoglobin level, white blood cell count, or platelet count fell below $85 \mathrm{~g} / \mathrm{dL}, 1 \times 10^{9} / \mathrm{L}$, and $2.5 \times 10^{9} / \mathrm{L}$, respectively.

\section{Definition of SVR and EVR}

SVR and EVR were defined as non-detectable HCV RNA as measured by the COBAS Amplicor HCV Monitor Test v2.0 (qualitative Amplicor) (Roche Diagnostics, Tokyo, Japan), and the results were labeled as positive or negative. The lower limit of detection was $50 \mathrm{IU} / \mathrm{mL}(0.5 \mathrm{kIU} /$ $\mathrm{mL}: 1.7 \log \mathrm{IU} / \mathrm{mL}$ ) [17]. Moreover, we compared serum HCV RNA negativity by the qualitative Amplicor assay with that by TaqMan assay during the initial 12 weeks of treatment.

\section{Determination of HCV RNA level}

During the treatment period (the initial 12 weeks: at week 2 , week 4 , week 8 , and week 12 ), we retrospectively determined serum HCV RNA level by both COBAS TaqMan 
Table 1: Characteristics of $\mathbf{8 0}$ genotype 1-infected chronic hepatitis $\mathrm{C}$ patients treated with pegylated interferon alpha $\mathbf{2 b}$ plus ribavirin combination, classified by the treatment response

\begin{tabular}{|c|c|c|c|c|}
\hline Characteristics & $\begin{array}{c}\text { Total } \\
\text { No. }=\mathbf{8 0}\end{array}$ & $\begin{array}{c}\text { SVR } \\
\text { No. }=39\end{array}$ & $\begin{array}{c}\text { Non-SVR } \\
\text { No. }=41\end{array}$ & P value \\
\hline Male No. (\%) & $36(45.0)$ & $17(43.6)$ & $19(46.3)$ & 0.9821 \\
\hline Age (years) & $57.4 \pm 9.8$ & $54.8 \pm 9.3$ & $59.8 \pm 9.7$ & 0.0133 \\
\hline Body Mass Index (kg/m²) & $23.0 \pm 3.1$ & $23.1 \pm 3.0$ & $23.6 \pm 3.4$ & 0.7821 \\
\hline Alanine aminotransferase (IU/L) & $89.9 \pm 65.4$ & $93.2 \pm 62.8$ & $86.5 \pm 65.7$ & 0.7832 \\
\hline Y-glutamyltranspeptidase (IU/L) & $59.2 \pm 54.0$ & $41.2 \pm 34.2$ & $77.3 \pm 33.1$ & 0.0548 \\
\hline Albumin (g/dL) & $4.2 \pm 0.4$ & $4.2 \pm 0.4$ & $4.0 \pm 0.4$ & 0.7105 \\
\hline White blood cell count $\left(10^{9} / \mathrm{L}\right)$ & $5.6 \pm 1.4$ & $5.3 \pm 1.4$ & $5.8 \pm 1.7$ & 0.4666 \\
\hline Hemoglobin ( $g / L)$ & $131 \pm 14$ & $133 \pm 14$ & $129 \pm 14$ & 0.2310 \\
\hline Platelet count $\left(10^{9} / \mathrm{L}\right)$ & $161 \pm 51$ & $167 \pm 45$ & $156 \pm 55$ & 0.1576 \\
\hline Creatinine (mg/dL) & $0.71 \pm 0.14$ & $0.69 \pm 0.16$ & $0.70 \pm 0.15$ & 0.3376 \\
\hline Creatinine clearance $(\mathrm{mL} / \mathrm{min})$ & $98.8 \pm 27.6$ & $100.2 \pm 28.7$ & $99.3 \pm 32.3$ & 0.4102 \\
\hline Histological cirrhosis No. (\%) & $6(7.5)$ & $2(5.1)$ & $4(9.7)$ & 0.6758 \\
\hline
\end{tabular}

HCV, hepatitis C virus

Data is shown as the mean \pm standard deviation.

SVR means a sustained virological response, which is defined as serum HCV RNA undetectable at 24 weeks after the end of treatment.

HCV assay (TaqMan) (Roche Diagnostics) and COBAS Amplicor HCV Monitor Test v2.0 using the 10-fold dilution method (Amplicor 10-fold method) (Roche Diagnostics) in each patient. The TaqMan has a lower limit of quantitation of $15 \mathrm{IU} / \mathrm{mL}$ and an outer limit of quantitation of $6.9 \times 10^{7} \mathrm{IU} / \mathrm{mL}$ (1.2 to $7.8 \mathrm{log} \mathrm{IU} / \mathrm{mL}$ referred to $\log _{10}$ units $/ \mathrm{mL}$ ) [14,15]. Therefore, TaqMan assay is able to do both qualitative and quantitative analysis for $\mathrm{HCV}$ RNA. The Amplicor 10-fold method has a lower limit of quantitation of $5,000 \mathrm{IU}(5 \mathrm{kIU} / \mathrm{mL})$ and an outer limit of quantitation of $5,100,000 \mathrm{IU}(5,100 \mathrm{kIU} / \mathrm{mL})$ [18]. To compare serum HCV RNA level by TaqMan assay with Amplicor 10-fold method assay, we transformed the level by Amplicor 10-fold method assay ( $\mathrm{kIU} / \mathrm{mL}$ ) into the logarithmic level $(\log \mathrm{IU} / \mathrm{mL})$. Therefore, the range of Amplicor 10-fold method is 3.7 to $6.7 \log \mathrm{IU} / \mathrm{mL}$.

\section{Determination of HCV genotype}

$\mathrm{HCV}$ genotype was determined using type-specific primers from the core region of the HCV genome. The protocol for genotyping was carried out as described earlier [19].

\section{Statistical analysis}

Statistical analysis was done with BMDP statistical software for the IBM 3090 system computer (BMBD Statistical Software, Inc., Los Angeles, CA, USA) for the IBM (Yorktown Heights, NY) 3090 computer system. Continuous data were expressed as mean values, mean \pm standard deviation (SD), or values \pm standard error (SE) of the mean. The paired t-test, unpaired t-test, Mann-Whitney $\mathrm{U}$ test or Kruskal-Wallis non-parametric analysis of variance was used to compare $\mathrm{HCV}$ dynamics. A P value less than 0.05 was regarded as statistically significant.

\section{Results}

The correlation of pretreatment HCV RNA levels between TaqMan and Amplicor 10-fold method assays

The relationship of pretreatment HCV RNA levels between TaqMan and Amplicor 10-fold method assays was studied in 39 SVR and 41 non-SVR patients infected with genotype 1 . The levels by TaqMan ranged from 4.4 to $7.2 \log \mathrm{IU} / \mathrm{mL}$ (median $6.1 \log \mathrm{IU} / \mathrm{mL}$ ) and those by Amplicor 10-fold method ranged from 5.0 to $6.7 \mathrm{log} \mathrm{IU} /$ $\mathrm{mL}$ (median $6.0 \log \mathrm{IU} / \mathrm{mL}$ ). We found a significantly positive correlation in the pretreatment HCV RNA level between TaqMan and Amplicor 10-fold method assays ( $\mathrm{r}$ $=0.849, \mathrm{P}<0.0001$ ).

Figure 1 shows pretreatment levels of HCV RNA classified by viral response (SVR or non-SVR). In TaqMan assay, the 39 SVR patients had significantly lower pretreatment HCV RNA level (median $5.89 \log \mathrm{IU} / \mathrm{mL}$ ) than the 41 non-SVR patients (median $6.25 \log \mathrm{IU} / \mathrm{mL})(\mathrm{P}=$ 0.0191). However, Amplicor 10-fold method assay showed no significant difference of pretreatment $\mathrm{HCV}$ RNA level between the SVR (median $5.91 \log \mathrm{IU} / \mathrm{mL}$ ) and non-SVR (median $6.09 \log \mathrm{IU} / \mathrm{mL})$ patients $(\mathrm{P}=0.0929)$. Therefore, pretreatment HCV RNA by TaqMan assay may be a predictive factor for SVR, but not by Amplicor 


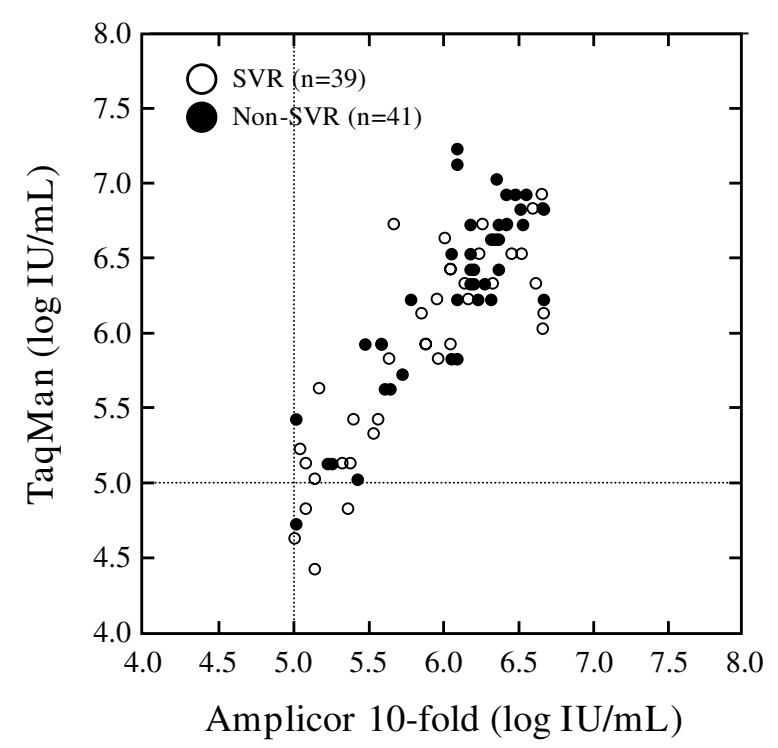

Figure 1 Correlation of pretreatment hepatitis $\mathrm{C}$ virus (HCV) RNA levels between TaqMan and Amplicor 10-fold method assays, classified by sustained virological response (SVR) and non-SVR. Open and closed circles mean SVR and non-SVR patients, respectively.

10-fold method assay among patients with HCV genotype 1.

The comparison with TaqMan and Amplicor 10-fold method assays in HCV dynamics within the initial 12 weeks of PEG-IFN plus RBV combined treatment

The relationship of HCV dynamics within the initial 12 weeks of the combined treatment between TaqMan and Amplicor 10-fold method assays was studied in 39 SVR and 41 non-SVR patients. Figure 2 shows the difference in the logarithmic decline from pretreatment HCV RNA level within the initial 12 weeks of the treatment between SVR and non-SVR patients by TaqMan and Amplicor 10fold method assays. The logarithmic declines of $\mathrm{HCV}$ RNA levels by TaqMan in SVR patients $(-3.54,-5.19$, and -5.65 at weeks 2,4 , and 8 , respectively) were significantly higher than those in non-SVR patients $(-2.23,-3.42$, and 4.68 at weeks 2,4 , and 8 , respectively) $(\mathrm{P}<0.0001, \mathrm{P}<$ 0.001 , and $\mathrm{P}=0.0012$, respectively), except for at weeks 12 ( -5.89 and $-5.75, \mathrm{P}=0.3936)$. Similarly, the logarithmic declines of HCV RNA levels by Amplicor 10-fold method assay in SVR patients $(-2.95,-4.36$, and -5.47 at weeks 2,4 , and 8 , respectively) were significantly higher than nonSVR patients $(-2.01,-3.09$, and -4.11 at weeks 2,4 , and 8 , respectively) $(\mathrm{P}=0.00281, \mathrm{P}=0.00021$, and $\mathrm{P}=0.0006$, respectively), except for at weeks $12(-5.91$ and $-6.09, \mathrm{P}=$ 0.0929). No significant difference in monitoring the HCV dynamics during the initial 12 weeks administration of the combined treatment was found between TaqMan and Amplicor 10-fold method assays.
The comparison with TaqMan and qualitative Amplicor assays in HCV RNA negativity within the initial 12 weeks of PEG-IFN plus RBV combined treatment

The undetectable HCV RNA by TaqMan was found in all of 39 SVR patients (100\%) but only in 24 of 41 non-SVR patients $(58.5 \%)$, while that by qualitative Amplicor was found in all of 39 SVR and 41 non-SVR patients. TaqMan reduced the numbers of undetectable HCV RNA in the group of non-SVR.

Figure 3 shows the distribution of timing of HCV RNA undetectable after the initiation of treatment at weeks 2 , 4,8 , and 12 in comparison with TaqMan and qualitative Amplicor assays. Among 39 SVR patients, the distributions of timing of detectable HCV RNA were 17.9\% (7/ $39), 43.6 \%(17 / 39), 0 \%(0 / 39)$, and $38.5 \%(15 / 39)$ by TaqMan and 17.9\% (7/39), 33.3\% (13/39), 30.8\% (12/39), and $17.9 \%$ (7/39) by qualitative Amplicor assay at 2, 4, 8 , and 12 weeks, respectively. There was no significant difference in timing of undetectable HCV RNA between TaqMan and qualitative Amplicor assays in the group of SVR. Among 41 non-SVR patients, the distribution of timing of detectable HCV RNA by TaqMan was 58.5\% (24/41) at 12 weeks, and those by qualitative Amplicor assay were $2.4 \%$ (7/41), 9.8\% (4/41), $21.9 \%(9 / 41)$, and $65.8 \%(27 / 41)$ at 2 , 4,8 , and 12 weeks, respectively. Patients of non-SVR had apparent delayed timing of undetectable HCV RNA, and the tendency was more frequently found by TaqMan than by qualitative Amplicor assay.

\section{The comparison with TaqMan and qualitative Amplicor assays for positive predictive value (PPV) rates of SVR in patients with EVR}

The PPV rates for SVR were calculated within the initial 12 weeks during the combined treatment, based on HCV RNA negativity by TaqMan and qualitative Amplicor assays, respectively. Figure 4 shows significant differences of the initial 12-week PPV rates for SVR were found between TaqMan assay (at weeks 4 and 8, 100\% and $100 \%$, respectively) and qualitative Amplicor $(80.0 \%$ and $69.6 \%$, respectively) assays. To predict SVR when patients have clearance of viremia, TaqMan assay is more useful than qualitative Amplicor assay in analysis of the early stage (within 8 weeks) of HCV dynamics.

\section{Discussion}

Measurement of serum HCV RNA level is absolutely imperative for the treatment of chronic HCV infection, because this is an effective predictive and indicative factor for the response of IFN therapy and duration of therapy $[7,9,10,20]$. A more useful analysis is the time to first undetectability and its relation to the end of treatment response, relapse rate and SVR [12]. Therefore, an advanced technique for detecting serum HCV RNA during the antiviral treatment needs a high degree of accu- 


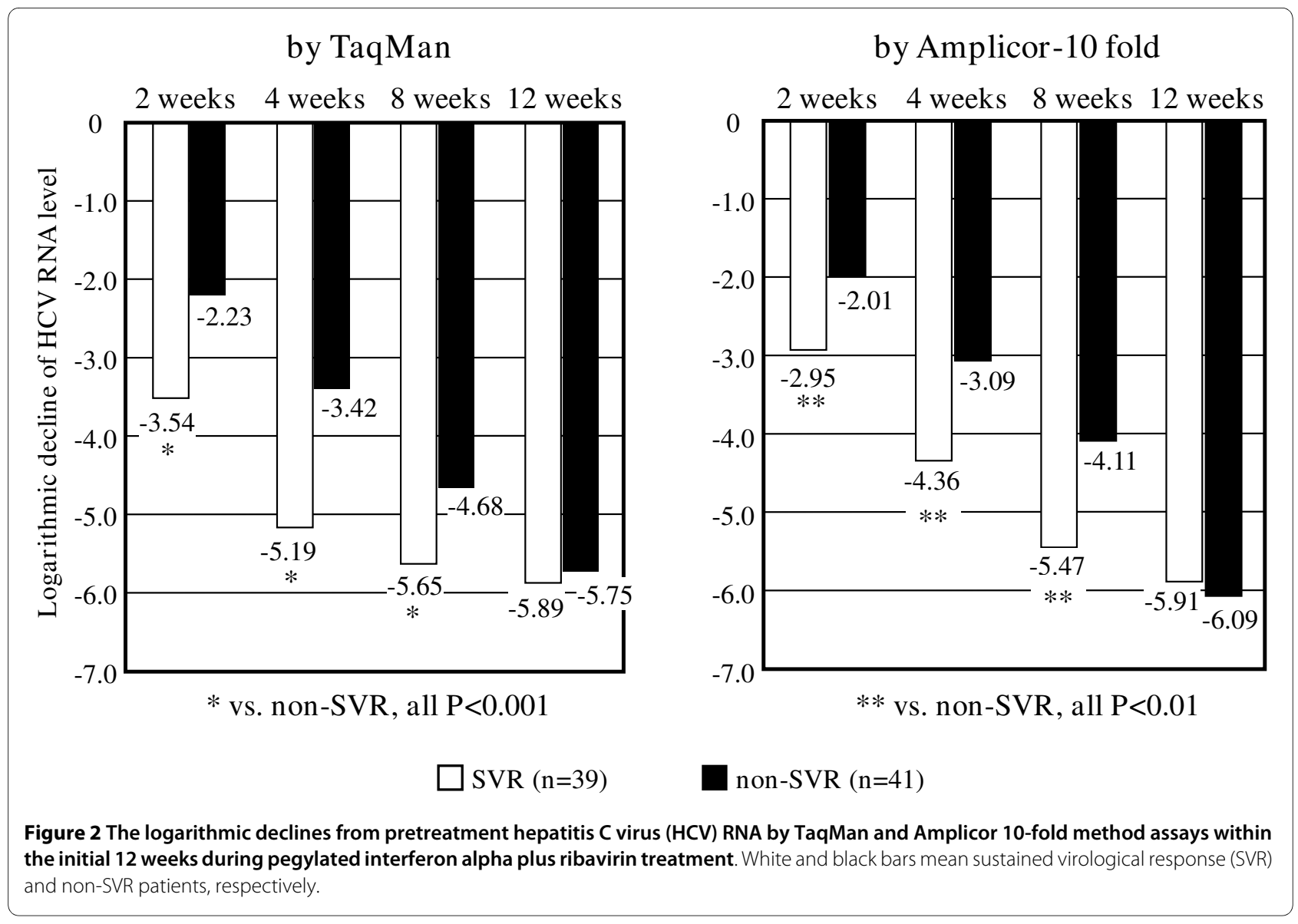

racy. The ideal molecular analysis for HCV RNA level has to be sensitive, accurate and have a broad dynamic range to monitor viral load changes during antiviral therapy. TaqMan assay is useful for simultaneously analyzing qualitative and quantitative HCV RNA level in serum $[14,15]$. The present study included only patients infected with chronic HCV genotype 1, who received a full of 48week treatment of PEG-IFN plus RBV combination with target dosages of both drugs (PEG-IFN alpha-2b $80 \%$ or over and RBV $60 \%$ or over of the above prescribed dosage). We believed that analyzing the exact response factors for antiviral treatment should be considered only under this enough dosage of the combined treatment [16]. The present study showed the superiority of TaqMan assay over Amplicor assay for analyzing the early prediction of virologic response to antiviral therapy.

TaqMan assay, the performance of a fully automated system based on the real-time PCR technology, was evaluated for nucleic acid extraction from plasma. This results in enhanced user convenience, a great reduction in labor requirements minimizing hands-on time and a decrease the risk of sample contaminations. TaqMan assay was extremely sensitive with a linear dynamic range up to $6.6 \log \mathrm{IU} / \mathrm{mL}(0.015-69,000 \mathrm{kIU} / \mathrm{mL}$ : $1.2-7.8 \log$
$\mathrm{IU} / \mathrm{mL}$ ) [14,15]. Otherwise, Amplicor 10-fold method assay had a narrower linear dynamic range up to $3.0 \mathrm{log}$ $\mathrm{IU} / \mathrm{mL}(5-5,000 \mathrm{kIU} / \mathrm{mL}: 3.7-6.7 \log \mathrm{IU} / \mathrm{mL})$ than TaqMan assay and qualitative Amplicor assay, the lower limit of detection was $50 \mathrm{IU} / \mathrm{mL}(1.7 \log \mathrm{IU} / \mathrm{mL})$ [17]. These different ranges can explain significant differences in the pretreatment HCV RNA levels and the reduction rates of HCV RNA levels during an antiviral treatment between TaqMan and Amplicor assays.

Previous studies demonstrated that PEG-IFN plus RBV treatment dramatically increased SVR rate in patients with HCV infection and thus are currently the gold standard of treatment $[3,4,7]$. The most significant predictors of SVR to IFN treatment for patients with chronic HCV infection are absence of severe fibrosis or cirrhosis, nongenotype 1 and pretreatment serum low HCV RNA level $[7,21,22]$. With regard to virological factor after the start of antiviral treatment, early clearance of HCV RNA, or rapid decline of HCV RNA level during the early treatment duration is predictive of SVR among patients treated with IFN treatment $[10,12,20]$. For monitoring of the antiviral response to IFN treatment, both reversetranscription PCR and branched DNA have been developed and have become available for clinical use 
SVR $(n=39)$

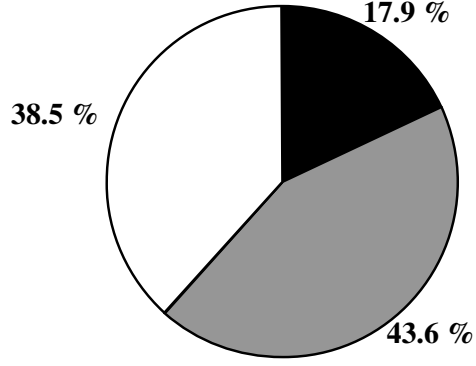

by TaqMan

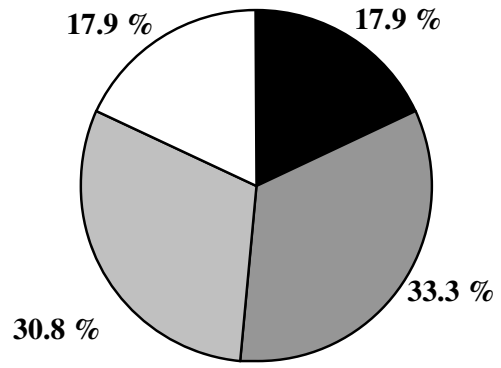

by qualitative Amplicor

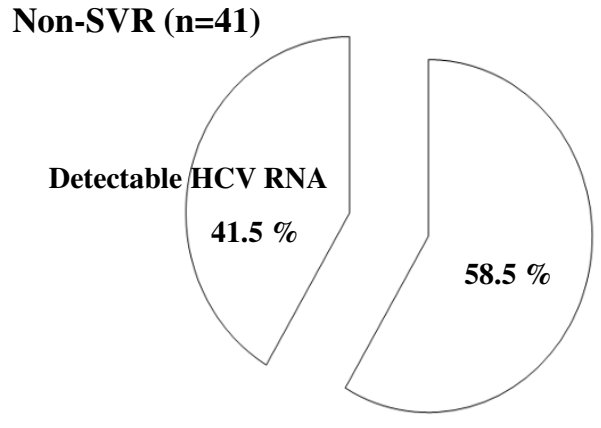

by TaqMan
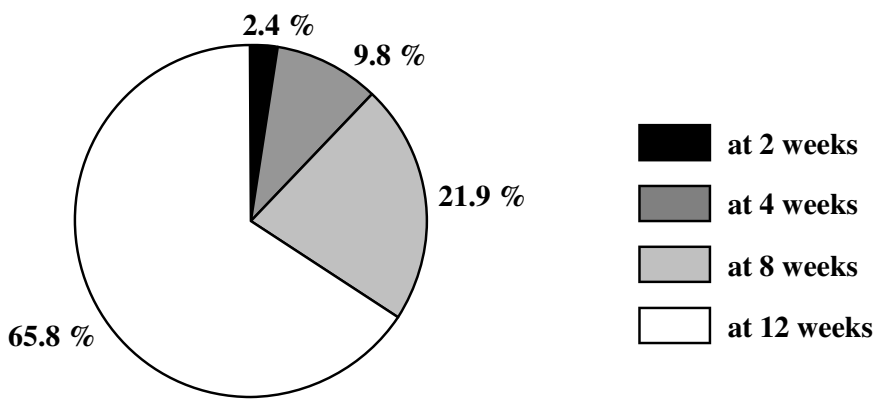

by qualitative Amplicor

Figure 3 The distribution of timing of HCV RNA undetectable after the initiation of treatment at weeks 2, 4, 8, and 12 in comparison with TaqMan and qualitative Amplicor assays. SVR, sustained virological response.

$[18,23,24]$. These assays are especially useful because the early monitoring of favorable viral kinetics has a direct bearing on the possibility of a sustained response by IFN treatment. Actually, our findings showed that pretreatment HCV RNA by TaqMan assay may be a predictive factor for SVR, but not by Amplicor 10-fold method assay, and that TaqMan assay is more useful than qualitative Amplicor assay in analysis of the early stage (at the initial 4 and 8 weeks) of $\mathrm{HCV}$ dynamics, which is most related with SVR. Early prediction of early virologic response to IFN based treatment can help identify patients who are unlikely to have SVR and allow clinicians to discontinuation of treatment, saving patients the drug-induced adverse events and cost of additional treatment.

Our results suggested that the reduction rates of $\mathrm{HCV}$ RNA levels were significantly higher than those in nonSVR patients both in TaqMan and Amplicor 10-fold method assays for patients having achieved SVR. However, in our analysis, significant differences of the initial 4 and 8 week PPV for SVR were found between Amplicor and TaqMan assays. PPV for SVR at 4 and 8 week was
$100 \%$ and $100 \%$ respectively in TaqMan assay, otherwise PPV for SVR was $80.0 \%$ and $69.6 \%$ respectively in qualitative Amplicor assay. In addition to EVR, within the initial 12 weeks undetectability of HCV RNA of the antiviral treatment, the critical role of rapid virological response (RVR), within the initial 4 weeks undetectability, on the SVR patients with genotype 1 and non-1 infection has been recently emphasized $[7,9,16]$. In fact, our findings showed more advantage using TaqMan assay on the PPV for SVR, especially at weeks 4 and 8, than Amplicor assay. Apparently, TaqMan assay is more accurate than Amplicor assay in analysis of the early stage (within 8 weeks) of HCV dynamics. PEG-IFN plus RBV treatment contributed to improve rates of SVR, but this rate is still lower for patients with $\mathrm{HCV}$ genotype 1 infection. Especially, most of Japanese patients with chronic hepatitis $C$ who are candidate for antiviral treatment are relatively older than other countries. As a result, a relapse rate with EVR was a little high regardless of adequate treatment. Therefore, analysis of HCV dynamics after the antiviral treatment, especially for these patients, is very important. 


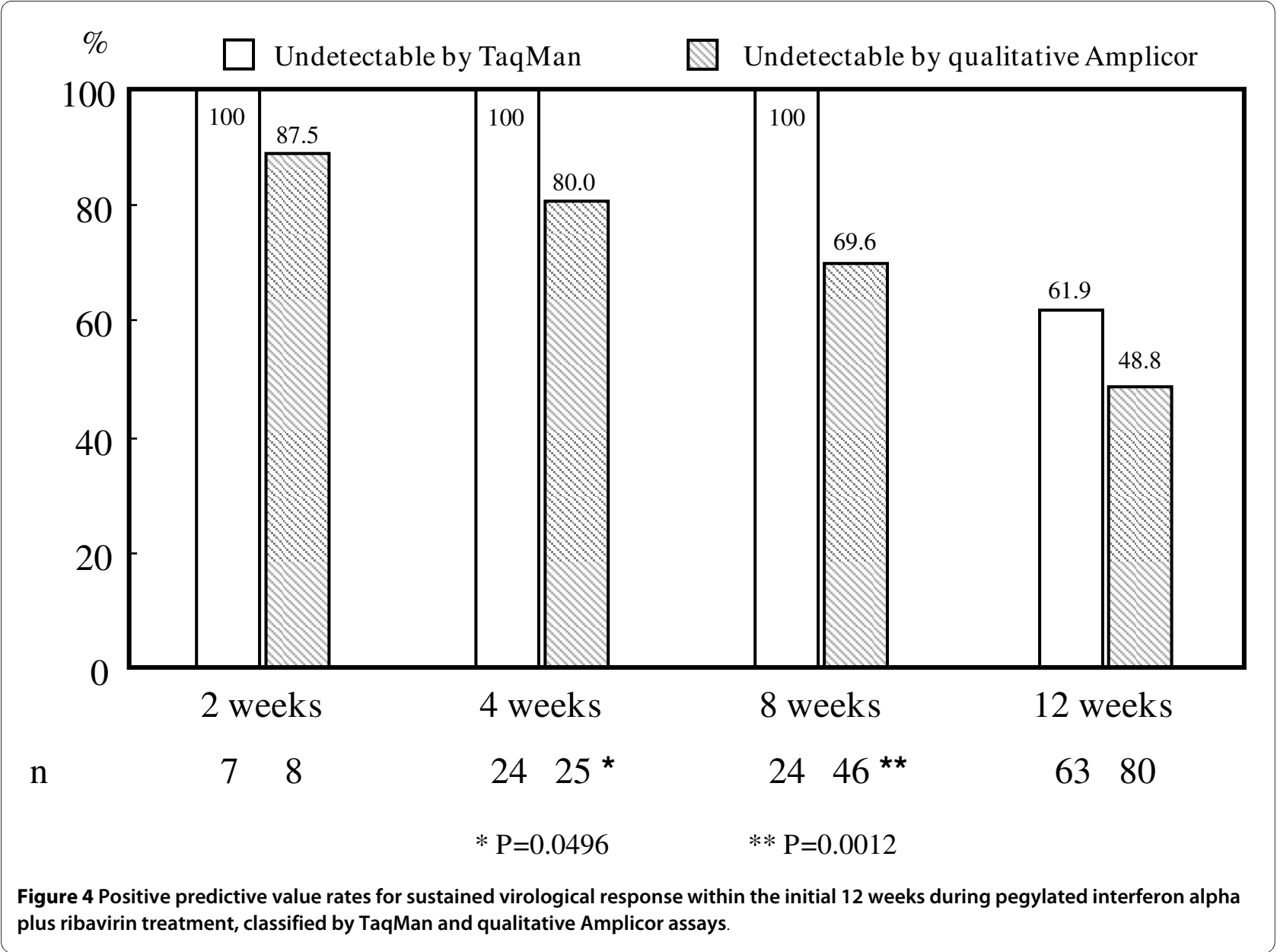

The present study showed that $21.3 \%$ of the patients with undetectable HCV RNA by qualitative Amplicor assay were positive for TaqMan assay within the initial 12 weeks during PEG-IFN plus RBV treatment. It is possible that qualitative Amplicor assay reveals late responders by the combined treatment in comparison with TaqMan assay. Berg and colleagues suggested extended treatment duration was recommended for patients with SVR as HCV RNA positive at week 12 but negative at week 24 [25]. About such patients, we need to extend the duration of the combination treatment of PEG-IFN alpha-2b plus RBV from 48 weeks to 72 weeks by an appearance of TaqMan assay.

\section{Conclusions}

In conclusion, the COBAS TaqMan HCV assay is useful for monitoring $\mathrm{HCV}$ viremia during antiviral treatment to predict a SVR in patients with chronically infected HCV genotype 1.

\section{Competing interests}

The authors declare that they have no competing interests.

\section{Authors' contributions}

EO performed the literature review, collected the clinical data and drafted the manuscript. NF, KT, HT, SO, MK, MM and YS collected the clinical data. NF participated in the design of the study and performed the statistical analysis. NF and $\mathrm{JH}$ revised the manuscript. All authors read and approved the final manuscript.

\section{Author Details}

'Department of General Internal Medicine, Kyushu University Hospital, Fukuoka, Japan and 2Department of Environmental Medicine and Infectious Disease, Kyushu University, Fukuoka, Japan

Received: 19 September 2008 Accepted: 16 April 2010 Published: 16 April 2010

\section{References}

1. Hayashi J, Kishihara Y, Yamaji K, Furusyo N, Yamamoto T, Pae Y, Etoh Y, Ikematsu H, Kashiwagi S: Hepatitis C viral quasispecies and liver damage in patients with chronic hepatitis C virus infection. Hepatology 1997, 25:697-701.

2. Benvegnu L, Gios M, Boccato S, Alberti A: Natural history of compensated viral cirrhosis: a prospective study on the incidence and hierarchy of major complications. Gut 2004, 53:744-9.

3. Lindsay KL, Trepo C, Heintges T, Shiffman ML, Gordon SC, Hoefs JC, Schiff ER, Goodman ZD, Laughlin M, Yao R, Albrecht JK, Hepatitis Interventional Therapy Group: A randomized, double-blind trial comparing pegylated interferon alfa-2b to interferon alfa- $2 b$ as initial treatment for chronic hepatitis C. Hepatology 2001, 34:395-403.

4. Chander G, Sulkowski MS, Jenckes MW, Torbenson MS, Herlong HF, Bass EB, Gebo KA: Treatment of chronic hepatitis C: a systematic review. Hepatology 2002, 36:S135-44. 
5. McHutchison JG, Gordon SC, Schiff ER, Shiffman ML, Lee WM, Rustgi VK, Goodman ZD, Ling MH, Cort S, Albrecht JK: Interferon alfa-2b alone or in combination with ribavirin as initial treatment for chronic hepatitis $\mathrm{C}$. Hepatitis Interventional Therapy Group. N Engl J Med 1998, 339:1485-92.

6. Poynard T, Marcellin P, Lee SS, Niederau C, Minuk GS, Ideo G, Bain V, Heathcote J, Zeuzem S, Trepo C, Albrecht J: Randomised trial of interferon alpha2b plus ribavirin for 48 weeks or for 24 weeks versus interferon alpha2b plus placebo for 48 weeks for treatment of chronic infection with hepatitis C virus. International Hepatitis Interventional Therapy Group (IHIT). Lancet 1998, 352:1426-32.

7. Furusyo N, Murata M, Hayashi J: Interferon treatment of hepatitis C virus infection: From basic biology to clinical application. In Hepatitis C virus disease: Immunology and Clinical Applications Edited by: Jirillo E. New York: Springer Science + Business Media, LLC; 2008:148-67.

8. Hayashi J, Kishihara Y, Ueno K, Yamaji K, Kawakami Y, Furusyo N, Sawayama $Y$, Kashiwagi S: Age-related response to interferon alfa treatment in women vs men with chronic hepatitis $C$ virus infection. Arch Intern Med 1998, 158:177-81.

9. Furusyo N, Katoh M, Tanabe Y, Kajiwara E, Maruyama T, Shimono J, Sakai H, Nakamuta M, Nomura H, Matsumoto A, Shimoda S, Takahashi K, Azuma K, Hayashi J, Kyusyu University Liver Disease Study Group: Interferon alpha plus ribavirin combination treatment of Japanese chronic hepatitis $C$ patients with HCV genotype 2: a project of the Kyushu University Liver Disease Study Group. World J Gastoroenterol 2006, 12:784-90.

10. Davis GL, Wong JB, McHutchison JG, Manns MP, Harvey J, Albrecht J: Early virologic response to treatment with peginterferon alfa-2b plus ribavirin in patients with chronic hepatitis C. Hepatology 2003, 38:645-52.

11. Lee SS, Heathcote EJ, Reddy KR, Zeuzem S, Fried MW, Wright TL, Pockros PJ, Häussinger D, Smith Cl, Lin A, Pappas SC: Prognostic factors and early predictability of sustained viral response with peginterferon alfa-2a (40KD). J Hepatol 2002, 37:500-6.

12. Ferenci $P$, Fried MW, Shiffman ML, Smith Cl, Marinos G, Gonçales FL Jr, Häussinger D, Diago M, Carosi G, Dhumeaux D, Craxì A, Chaneac M, Reddy KR: Predicting sustained virological responses in chronic hepatitis $C$ patients treated with peginterferon alfa-2a (40 KD)/ribavirin. J Hepatol 2005, 43:425-33.

13. Gerken G, Rothaar T, Rumi MG, Soffredini R, Trippler M, Blunk MJ, Butcher A, Soviero S, Colucci G: Performance of the COBAS AMPLICOR HCV MONITOR test, version 2.0, an automated reverse transcription-PCR quantitative system for hepatitis $C$ virus load determination. J Clin Microbiol 2000, 38:2210-4

14. Sandres-Sauné K, Abravanel F, Nicot F, Peron JM, Alric L, Boineau J, Pasquier C, Izopet J: Detection and quantitation of HCV RNA using realtime PCR after automated sample processing. J Med Virol 2007, 79:1821-6.

15. Sizmann D, Boeck C, Boelter J, Fischer D, Miethke M, Nicolaus S, Zadak M, Babiel R: Fully automated quantification of hepatitis $C$ virus (HCV) RNA in human plasma and human serum by the COBAS AmpliPrep/COBAS TaqMan system. J Clin Virol 2007, 38:326-33.

16. Furusyo N, Kajiwara E, Takahashi K, Momura H, Tanabe $Y$, Masumoto A, Maruyama T, Nakamuta M, Enjoji M, Azuma K, Shimono J, Sakai H, Shimoda S, Hayashi J, Kyushu University Liver Disease Study (KULDS) Group: Association between the treatment length and cumulative dose of pegylated interferon alpha- $2 b$ plus ribavirin and their effectiveness as a combination treatment for Japanese chronic hepatitis C patients: Project of the Kyushu University Liver Disease Study Group. J Gastroenterol Hepatol 2008, 23:1094-104.

17. Lee SC, Antony A, Lee N, Leibow J, Yang JQ, Soviero S, Gutekunst K, Rosenstraus M: Improved version 2.0 qualitative and quantitative AMPLICOR reverse transcription-PCR tests for hepatitis $C$ virus RNA: calibration to international units, enhanced genotype reactivity, and performance characteristics. J Clin Microbiol 2000, 38:4171-9.

18. Ogawa E, Furusyo N, Toyoda K, Takeoka H, Otaguro S, Hamada M, Murata M, Sawayama Y, Hayashi J: Transient elastography for patients with chronic hepatitis $B$ and $C$ virus infection: Non-invasive, quantitative assessment of liver fibrosis. Hepatol Res 2007, 37:1002-10.

19. Simmonds $P$, Holmes SC, Cha TA, Chan SW, McOmish S, Irvine B, Beall E, Yap PL, Kolberg J, Urdea MS: Classification of hepatitis $C$ virus into six major genotypes and a series of subtypes by phylogenetic analysis of the NS-5 region. J Gen Virol 1993, 74:2391-9.
20. Neumann AU, Lam NP, Dahari H, Gretch DR, Wiley TE, Layden TJ, Perelson AS: Hepatitis $C$ viral dynamics in vivo and the antiviral efficacy of interferon-alpha therapy. Science 1998, 282:103-7.

21. Strader DB, Wright T, Thomas DL, Seeff LB: American Association for the Study of Liver Disease. Diagnosis, management, and treatment of hepatitis C. Hepatology 2004, 39:1147-71.

22. Alberti A, Benvegnu L: Management of hepatitis C. J Hepatol 2003, 36:S104-18

23. Hayashi J, Kawakami Y, Nabeshima A, Kishihara Y, Furusyo N, Sawayama Y, Kinukawa N, Kashiwagi S: Comparison of HCV RNA levels by branched DNA probe assay and by competitive polymerase chain reaction to predict effectiveness of interferon treatment for patients with chronic hepatitis C virus. Dig Dis Sci 1998, 43:384-91.

24. Furusyo N, Hayashi J, Kashiwagi K, Nakashima H, Nabeshima S, Sawayama Y, Kinukawa N, Kashiwagi S: Hepatitis C virus (HCV) RNA level determined by second-generation branched-DNA probe assay as predictor of response to interferon treatment in patients with chronic HCV viremia. Dig Dis Sci 2002, 47:535-42.

25. Berg $T$, von Wagner M, Nasser S, Sarrazin C, Heintges T, Gerlach T, Buggisch P, Goeser T, Rasenack J, Pape GR, Schmidt WE, Kallinowski B, Klinker H, Spengler U, Martus P, Alshuth U, Zeuzem S: Extended treatment duration for hepatitis $C$ virus type 1 : comparing 48 versus 72 weeks of peginterferon-alfa-2a plus ribavirin. Gastroenterology 2006 130:1086-97.

\section{Pre-publication history}

The pre-publication history for this paper can be accessed here: http://www.biomedcentral.com/1471-230X/10/38/prepub

doi: $10.1186 / 1471-230 X-10-38$

Cite this article as: Ogawa et al., Excellent superiority and specificity of COBAS TaqMan HCV assay in an early viral kinetic change during pegylated interferon alpha-2b plus ribavirin treatment BMC Gastroenterology 2010, 10:38

\section{Submit your next manuscript to BioMed Centra and take full advantage of:}

- Convenient online submission

- Thorough peer review

- No space constraints or color figure charges

- Immediate publication on acceptance

- Inclusion in PubMed, CAS, Scopus and Google Scholar

- Research which is freely available for redistribution 